UDC 613.2

DOI: $10.21668 /$ health.risk/2018.2.03.eng

Read

\title{
IRRATIONAL NUTRITION AS POPULATTION HEALTH RISK FACTOR IN IRKUTSK REGION
}

\author{
I.G. Zhdanova-Zaplesvichko ${ }^{1,2}$ \\ ${ }^{1}$ Federal Service for Surveillance over Consumer Rights Protection and Human Well-being, Irkutsk Regional \\ Office, 8 Karl Marks Str., Irkutsk, 664003, Russian Federation \\ ${ }^{2}$ Irkutsk State Medical Academy for Post-graduate Studies, a branch of Russian Medical Academy for Continuous \\ Occupational Education, 100 Yubileyniy district, Irkutsk, 664049, Russian Federation
}

Insufficient and unsafe nutrition causes a lot of diseases. The article contains assessment of long-term (2006-2016) dynamics describing food products consumption by Irkutsk region population, and food substances contents in consumed food products. The author analyzed population morbidity in Irkutsk region in terms of basic alimentary-dependent diseases, groups of diseases, and specific nosologic forms, and compared it with average country and regional morbidity; she also assessed prevalence of "irrational nutrition" factor among adult population.

It was deleted that there was a deficiency in basic food products consumption by Irkutsk region population; basic food products were consumed in smaller quantities than in the country on average. Taken in dynamics over 2006-2012, consumption of proteins, fats, hydrocarbons, as well as caloric value of consumed food tended to grow. But then, taken in dynamics over 2012-2016, all these parameters decreased.

The author analyzed alimentary-dependent population morbidity in Irkutsk region over 2012-2016 and detected more negative trends in it in comparison with the average country levels. Morbidity with most analyzed categories and groups of diseases and specific alimentary-dependent diseases were higher in Irkutsk region than in the country on average. There were negative trends detected in dynamics of morbidity caused by such a risk factor as unhealthy nutrition (blood diseases; endocrine system diseases, including obesity; thyroid gland diseases; thyrotoxicosis; diseases related to increased blood pressure; digestive organs diseases).

Key words: population nutrition, basic food substances, caloric value, alimentary-dependent morbidity, diseases categories, nosologic forms, irrational nutrition

Healthy nutrition is one of the state policy priorities in the field of public health. Prevention of diseases caused by inadequate and unbalanced nutrition, preservation and strengthening of public health are the main goals of the state policy in the field of healthy nutrition ${ }^{1}$. It's been established that as a result of a complex of activities in which nutrition plays a leading role, it is realistic and quick enough to im- prove public health $[1,2]$.

Disturbances in the structure of nutrition largely determine high morbidity and mortality from cardiovascular and other non-infectious diseases. Therefore, the problem of food safety in the region is viewed both from the standpoint of food consumption adequacy to physiological needs of a human, and from the standpoint of sanitary and epidemiological safety, that

(C) Zhdanova-Zaplesvichko I.G., 2018

Inga G. Zhdanova-Zaplesnevichko - Candidate of Medical Sciences, Head of Organizational Department; Associate Professor at Public Health and Healthcare Department (e-mail: zhd i@mail.ru; tel.: +7 (914) 935-23-27).

${ }^{1}$ Ob osnovakh gosudarstvennoi politiki Rossiiskoi Federatsii v oblasti zdorovogo pitaniya naseleniya na period do 2020 goda: Rasporyazhenie Pravitel'stva RF № 1873-r ot 25.10.2010 g. [On the fundamentals of the Russian Federation state policy in the field of healthy nutrition of the population for the period up to 2020: Order of the Russian Federation Government of 25.10.2010 No. 1873-r]. Kosul'tantPlyus. Available at: http://www.consultant.ru/document/cons doc LAW 106196/ (30.01.2018) (in Russian). 
is, protection of an organism internal environment from ingesting various xenobiotics of chemical and biological nature. In view of the above, providing the population of our country with safe agricultural products, fish and other products from aquatic resources and food is a strategic goal of food safety. To assess food safety status, the following indices which includes: food consumption per capita; daily human nutrition caloric intake; amount of proteins, fats, carbohydrates, vitamins, macro- and microelements consumed by a person per day, and others ${ }^{2}$ are in use.

Studies of the actual nutrition of the population, carried out in recent years in various regions of the country, showed presence of both general and specific problems that depend on socioeconomic, environmental and production factors, as well as on the traditions of nutrition [3]. In most countries, there is a distinct tendency to increasing prevalence of alimentarydependent pathology [2, 4, 5]. Unhealthy diet, overweight and obesity contribute to the development of many non-infectious diseases, including cardiovascular diseases, type II diabetes, and certain types of cancer, which together are the main causes of death. In most countries, examinations of population indicate an excessive consumption of calories, saturated fats, transfats, sugar and salt, inadequate consumption of vegetables, fruits and whole grains, and an increase in the number of obese people. It is established that these factors not only reduce the prospective life expectancy, but also worsen the quality of life [4, 6-12].

Nutrition of the Irkutsk region population is characterized by a sharp imbalance in its structure, a lack of micro and macronutrients, eating disorders, which can lead to the development of diseases associated with the influence of alimentary factor [13].

The purpose of this study is to analyze the dynamics and levels of food products consumption and the main nutritional diseases in the Irkutsk region population, to give a comparative description in relation to the average Russian and regional indices.

Materials and methods. To study the population nutritional status we used Rosstat data over the period 2005-2016 $[14,15]$. The norms of food consumption are given in accordance with the Order of the Ministry of Health of Russia, ddt. 19.08.2016, No. 614 "On approval of recommendations on rational norms for consumption of food that meet modern requirements for healthy eating" ${ }^{3}$. Prevalence of "improper nutrition" factor was estimated according to the statistical report form No. 131 «"Information on clinical examination of certain adult population groups" ${ }^{4}$ for 2014-2016. Analysis of the alimentarydependent incidence in the population was

${ }^{2} \mathrm{Ob}$ utverzhdenii Doktriny prodovol'stvennoi bezopasnosti Rossiiskoi Federatsii: Ukaz Prezidenta RF № 120 ot 30.01.2010 g. [On approval of the Food Security Doctrine of the Russian Federation: Presidential Decree of 30.01.2010 No. 120]. Kosul'tantPlyus. Available at: http://www.consultant.ru/document/cons doc_LAW_96953// (30.01.2018) (in Russian).

${ }^{3} \mathrm{Ob}$ utverzhdenii rekomendatsii po ratsional'nym normam potrebleniya pishchevykh produktov, otvechayushchikh sovremennym trebovaniyam zdorovogo pitaniya: Prikaz Minzdrava Rossii № 614 ot 19.08.2016 g. [On approval of recommendations on rational norms for consumption of food that meet modern requirements for healthy nutrition: Order of the Ministry of Health of Russia ddt. 19.08.2016 No. 614]. Konsul'tantPlyus. Available at: http://www.consultant.ru/document/cons doc LAW 204200/ (13.03.2018) (in Russian).

${ }^{4}$ Svedeniya o dispanserizatsii opredelennykh grupp vzroslogo naseleniya: obrazets (forma) № 131 [Data on clinical examination of certain groups of adults: Form No.131]. KODEKS: elektronnyi fond pravovoi i normativno-tekhnicheskoi dokumentatsii. Available at: $\underline{\mathrm{http}: / / \text { docs.cntd.ru/do }} \neg$ cument/493676665 (13.03.2018) (in Russian). 
carried out for the period 2012-2016, according to the Ministry of Health of Russia [16-18]. Data were statistically processed using classical methods.

Results and discussion. It was established that in Irkutsk region there is a deficit (comparing to the recommended consumption norms) in a number of important groups of food products (Table 1). It should also be noted that Irkutsk region belongs to the Russian Federation group of subjects with a lower level of consumption of staple foods comparing to the average Russian indices, except for vegetable oil and potatoes $\left(32^{\text {nd }}\right.$ and $28^{\text {th }}$, respectively), and ranks $51^{\text {st }}-73^{\text {rd }}$ among 85 subjects of the Russian Federation.

Following the data in Table 1, the consumption of meat and meat products in 2016 was $68 \mathrm{~kg}$ per capita, per year in Irkutsk region (at a standard value of 73 $\mathrm{kg} /$ year) and was below the recommended norm of $5 \mathrm{~kg}$ (by $6.8 \%$ ). In the dynamics for the period 2005-2016, there is a significant increase in meat consumption $(+28.3$ $\%$ ). At the same time, in the recent 3 years there has been a decrease in consumption of meat products by $3 \%$.

Table 1

Consumption of basic food products by the population of Irkutsk region (per capita, per year, $\mathrm{kg}$ )

\begin{tabular}{|l|c|c|c|c|c|c|c|c|c|}
\hline \multicolumn{1}{c}{$\begin{array}{c}\text { Product groups } \\
\text { (rating for 2016)* }\end{array}$} & 2005 & 2010 & 2011 & 2012 & 2013 & 2014 & 2015 & 2016 & $\begin{array}{c}\text { Recommended con- } \\
\text { sumption, kg/ per- } \\
\text { son/year }\end{array}$ \\
\hline Meat and meat products (51) & 53 & 62 & 66 & 69 & 70 & 70 & 68 & 68 & 73 \\
\hline Milk and dairy products (64) & 184 & 190 & 198 & 202 & 199 & 200 & 197 & 193 & 325 \\
\hline Eggs, pcs. (58) & 174 & 203 & 208 & 213 & 219 & 224 & 230 & 232 & 260 \\
\hline Vegetables and cucurbits crops (73) & 63 & 77 & 82 & 84 & 83 & 84 & 85 & 86 & 140 \\
\hline Sugar (67) & 29 & 32 & 34 & 34 & 33 & 32 & 31 & 32 & 24 \\
\hline Vegetable oil (32) & 11,8 & 11,7 & 12,7 & 13,4 & 13,0 & 13,0 & 12,7 & 12,9 & 12 \\
\hline Potatoes (28) & 130 & 123 & 127 & 125 & 125 & 127 & 126 & 126 & 90 \\
\hline Bread products (64) & 120 & 109 & 113 & 113 & 108 & 105 & 106 & 106 & 96 \\
\hline
\end{tabular}

Note: * - Rating among 85 subjects of Russian Federation (in descending order)

Consumption of milk and dairy products in Irkutsk region in 2016 was 193 $\mathrm{kg}$ per capita, per year, which is lower than the recommended norm by $132 \mathrm{~kg}(1.7$ times). According to the consumption of milk and dairy products among 85 subjects of Russian Federation, Irkutsk region held $64^{\text {th }}$ rating position. Evaluation of the dynamics in this index for the period 20052016 shows presence of multidirectional trends, including growth of dairy products consumption in the period 2005-2012 (growth rate $+9.8 \%$ ), and decline trends for this index in the following period 2012-2016 (decline rate is $4.5 \%$ ). In 3 years dynamics, there is a decrease in consumption of dairy products by $3.5 \%$.

Consumption of eggs in Irkutsk region in 2016 was 232 pcs. per capita, per year, which is below the recommended value by 28 pcs. (by $10.8 \%$ ). By the consumption of eggs among 85 subjects of Russian Federation, Irkutsk region ranked $58^{\text {th }}$. In the dynamics for 2005-2016, there is a significant increase in consumption of this type of products $(+33.3 \%)$.

Consumption of vegetables and cucurbits crops in Irkutsk region was $86 \mathrm{~kg}$ per capita, per year, which is below the recommended norm by $54 \mathrm{~kg}$ (1.6 times). 
In 2016 , Irkutsk region held $73^{\text {rd }}$ rating in the consumption of this product per capita. In the dynamics for 2005-2016, there is a significant increase in consumption of vegetables and cucurbits crops $(+36.5 \%)$.

Consumption of potatoes, sugar, bread products and vegetable oil in Irkutsk region exceeded the recommended standards.

The consumption of potato was 126 $\mathrm{kg}$, which is $36 \mathrm{~kg}$ higher than the recommended value (1.4 times). Among 85 subjects of Russian Federation, Irkutsk region ranked $28^{\text {th }}$. In the dynamics for 20052016 , potato consumption significantly decreased $(-3.1 \%)$, over the recent 3 years, the consumption level is characterized by a tendency to stabilization of this index (126-127 kg/year).

Consumption of sugar was $32 \mathrm{~kg}$, which is higher than the recommended norm by $8 \mathrm{~kg}$ (by $33 \%$ ). Evaluation of this indicator in dynamics for the period 20052016 shows presence of multidirectional trends, including a growth trend in sugar consumption for 2005-2011 (+ $17.2 \%)$, stabilization of consumption in 2011-2012, and the decline trend in this index in the following period: the decline for the period 2012-2016 made $5.9 \%$.

Consumption of bread products made $106 \mathrm{~kg} /$ person per year, which is higher than the recommended norm by 10 $\mathrm{kg}$ (by $10.4 \%$ ). In dynamics, for the period 2005-2016, there is a significant decrease in bread products consumption $(-11.7 \%)$.

Consumption of vegetable oil in 2016 was $12.9 \mathrm{~kg}$, which is $7.5 \%$ higher than the recommended norm $(0.9 \mathrm{~kg})$. Evaluation of this index in dynamics for the period 2005-2016 speaks for multidirectional trends. Thus, in the period 20052012, there was an increase in vegetable oil consumption $(+13.6 \%)$, and the trend of decline in this index in the following period (the decline for the period 2012-2016 made $3.7 \%$ ).

Caloric intake of food products by the population in Irkutsk region in 2000 was 2,757.8 calories per consumer, per day, which is $3.1 \%$ higher than the Russian average (2674.8 kcal) (Figure).

Excess in food ration caloric content in Irkutsk region relative to the Russia's average level is due to a higher carbohydrate intake (in 2016: by $6.3 \%$ ), fat (by $0.6 \%$ ). Consumption of protein in Irkutsk region population diet for 2016 was lower than the average Russian index by $2.3 \%$. The dynamics for the period 2006-2016 in Irkutsk region observes two different trends: in the period of 2006-2012, the growth tendency in consumption of proteins, fats, carbohydrates and calories content of the diet was $19.1 \%, 29 \%, 8.1 \%, 15.9 \%$, respectively. In the period 2012-2016, the decrease tendency in the dietary intake of protein, fat, carbohydrate and caloric intake itself - by $5.6 \%, 5.9 \%, 9.9 \%$ and 8 $\%$ respectively (Table 2 ).

Thus, nutrition of the population in Irkutsk region is unbalanced; there is a significant gap between the recommended norms for the consumption of vegetables and fruits, milk and dairy products (more than 1.5 times), eggs, meat products, which causes deficit in protein and fiber in a diet. At the same time, an excessive consumption of carbohydrates is noted, among other things, due to potatoes, sugar, grain products.

The high prevalence of "improper nutrition" factor in the adult population is confirmed by the medical examination data. According to the data for 2016, this risk factor was registered in $30.1 \%$ of persons who passed medical examination (2013: $22.7 \%$, 2014: 30.1\%, 2015: $29.4 \%$ ). 
$\mathrm{kcal} / \mathrm{day}$

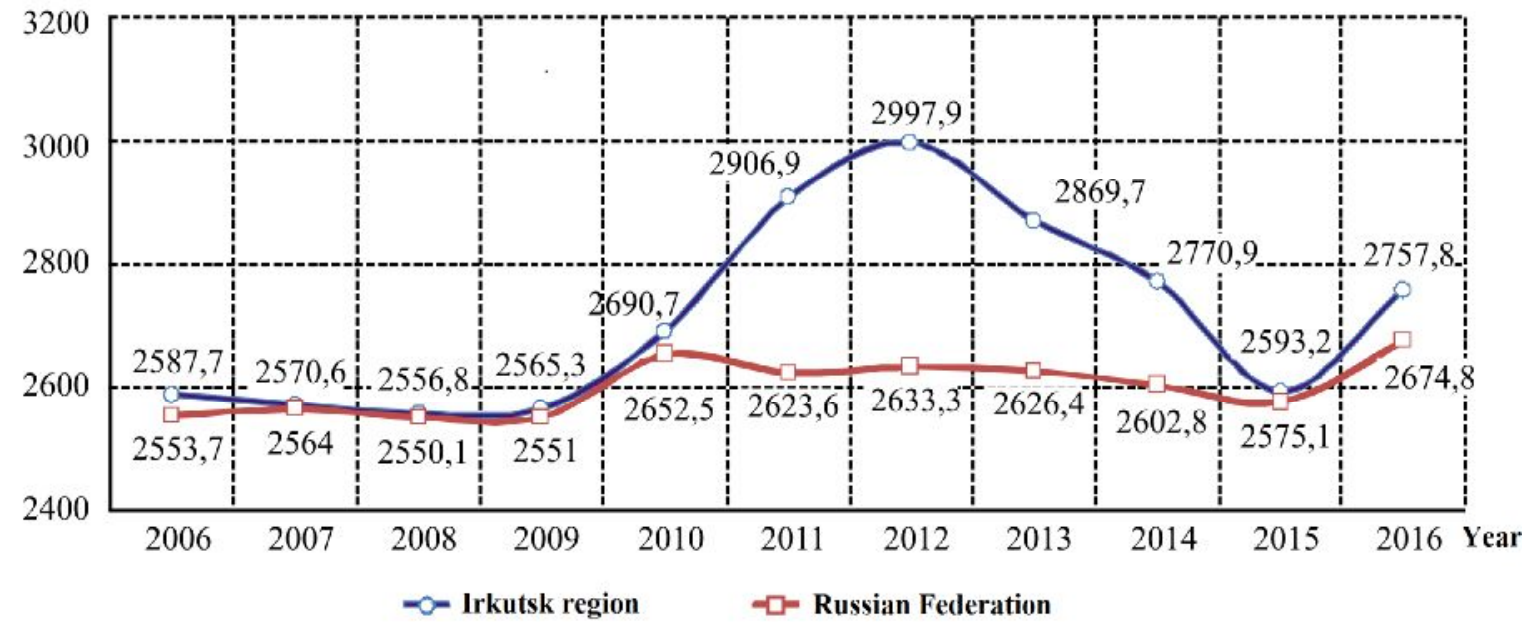

Figure. Caloric intake of food products by the population of Irkutsk region

(on average, per household member, per day)

Table 2

Composition of nutrients in the consumed food products in Irkutsk region and Russian Federation for 2006-2016

\begin{tabular}{|c|c|c|c|c|c|c|c|c|}
\hline \multirow{3}{*}{ Year } & \multicolumn{8}{|c|}{ Quantity of nutrients (per consumer, per day) } \\
\hline & \multicolumn{2}{|c|}{ Proteins, g. } & \multicolumn{2}{|c|}{ Fats, $g$} & \multicolumn{2}{|c|}{ Carbohydrates, $\mathrm{g}$} & \multicolumn{2}{|c|}{ kcal } \\
\hline & $\begin{array}{l}\text { Irkutsk } \\
\text { region }\end{array}$ & $\mathrm{RF}$ & $\begin{array}{l}\text { Irkutsk } \\
\text { region }\end{array}$ & $\mathrm{RF}$ & $\begin{array}{l}\text { Irkutsk } \\
\text { region }\end{array}$ & $\mathrm{RF}$ & $\begin{array}{l}\text { Irkutsk } \\
\text { region }\end{array}$ & $\mathrm{RF}$ \\
\hline 2006 & 69,5 & 70,7 & 90,1 & 95,2 & 372,2 & 350,8 & 2587,7 & 2553,7 \\
\hline 2007 & 69,1 & 71,7 & 90,4 & 97,4 & 367,5 & 347,4 & 2570,6 & 2564,0 \\
\hline 2008 & 70,7 & 72,8 & 92,3 & 98,5 & 358 & 340,4 & 2556,8 & 2550,1 \\
\hline 2009 & 71,5 & 73,3 & 95,2 & 99,3 & 352,9 & 338,2 & 2565,3 & 2551,0 \\
\hline 2010 & 75,3 & 76,6 & 101,5 & 104,5 & 366,4 & 348,4 & 2690,7 & 2652,5 \\
\hline 2011 & 81,0 & 76,7 & 109,3 & 104,7 & 396,8 & 340,6 & 2906,9 & 2623,6 \\
\hline 2012 & 82,8 & 77,5 & 116,2 & 105,3 & 402,3 & 341 & 2997,9 & 2633,3 \\
\hline 2013 & 80,1 & 78,1 & 114,2 & 106,2 & 377,6 & 336,5 & 2869,7 & 2626,4 \\
\hline 2014 & 78,4 & 77,7 & 110,7 & 105,3 & 362,3 & 333 & 2770,9 & 2602,8 \\
\hline 2015 & 73,5 & 77,1 & 103,2 & 104,6 & 339,9 & 328,4 & 2593,2 & 2575,1 \\
\hline 2016 & 78,2 & 80,0 & 109,3 & 108,7 & 362,6 & 341,1 & 2757,8 & 2674,8 \\
\hline
\end{tabular}

The diet imbalance leads to an increased level and growth in the incidence rates of endocrine system diseases (thyroid diseases, thyrotoxicosis, type 2 diabetes, obesity, blood diseases, including anemia, cardiovascular system) and other alimentary-dependent diseases.
Analysis of the alimentary-dependent morbidity of the entire population in Irkutsk region, for the period 2012-2016, testifies that the average long-term levels of this pathology in Irkutsk region for most of the analyzed classes, groups of diseases, and certain diseases were higher than the average Russia's values (Table 3). 
Table 3

Morbidity in the whole population, per classes, groups of diseases, and certain diseases diagnosed first time in life for the period 2014-2016 (per 100 th. people of the population)

\begin{tabular}{|c|c|c|c|c|c|c|}
\hline Region & 2012 & 2013 & 2014 & 2015 & 2016 & $\begin{array}{c}\text { Long-term annual } \\
\text { average for 2012-2016 }\end{array}$ \\
\hline \multicolumn{7}{|c|}{ In total } \\
\hline Irkutsk region & 92057,1 & 94560,2 & 95607,4 & 95218,9 & 99980,3 & 95484,8 \\
\hline Siberian Federal District & 84611,4 & 86943,7 & 86041,9 & 84796,6 & 85056,4 & 85490,0 \\
\hline Russian Federation & 79390,4 & 80030,3 & 78615,7 & 77815,7 & 78602,1 & 78890,8 \\
\hline \multicolumn{7}{|c|}{ Blood diseases } \\
\hline Irkutsk region & 529,3 & 558,4 & 588 & 602,6 & 607,4 & 577,1 \\
\hline Siberian Federal District & 520,5 & 525,8 & 521,8 & 510,4 & 515,5 & 518,8 \\
\hline Russian Federation & 471,2 & 466,1 & 470,5 & 472,4 & 469,5 & 469,9 \\
\hline \multicolumn{7}{|c|}{ incl. anemia } \\
\hline Irkutsk region & 481,9 & 511,8 & 544,5 & 547,8 & 548,5 & 526,9 \\
\hline Siberian Federal District & 483,8 & 491 & 481,1 & 463,3 & 476,5 & 479,1 \\
\hline Russian Federation & 429,2 & 424,8 & 427,2 & 433,9 & 433,1 & 429,6 \\
\hline \multicolumn{7}{|c|}{ Diseases of endocrine system } \\
\hline Irkutsk region & 1784,7 & 1760,6 & 1882,9 & 1841,7 & 2017 & 1857,4 \\
\hline Siberian Federal District & 1382,8 & 1405,9 & 1479,6 & 1700,9 & 1910,5 & 1575,9 \\
\hline Russian Federation & 1061 & 1065 & 1118,4 & 1333,8 & 1390,4 & 1193,7 \\
\hline \multicolumn{7}{|c|}{ incl. thyroid gland diseases } \\
\hline Irkutsk region & 664,1 & 607,9 & 690 & 671,2 & 730,1 & 672,7 \\
\hline Siberian Federal District & 463,4 & 465,4 & 466,4 & 486,1 & 501,2 & 476,5 \\
\hline Russian Federation & 354,3 & 339,5 & 346,9 & 357,7 & 355,1 & 350,7 \\
\hline \multicolumn{7}{|c|}{ incl. thyrotoxicosis } \\
\hline Irkutsk region & 23,4 & 20 & 19,4 & 24,1 & 25,8 & 22,5 \\
\hline Siberian Federal District & 19,7 & 17,6 & 18,2 & 20,9 & 21,6 & 19,6 \\
\hline Russian Federation & 15,2 & 14,5 & 15 & 16,6 & 17,2 & 15,7 \\
\hline \multicolumn{7}{|c|}{ incl. obesity } \\
\hline Irkutsk region & 250,4 & 312,3 & 336,1 & 344,9 & 367,7 & 322,3 \\
\hline Siberian Federal District & 301,4 & 353,2 & 368 & 458,3 & 483,5 & 392,9 \\
\hline Russian Federation & 172,9 & 206,4 & 228,3 & 314,8 & 317,3 & 247,9 \\
\hline \multicolumn{7}{|c|}{ incl. type 2 diabetes mellitus } \\
\hline Irkutsk region & 224,5 & 224,7 & 212,1 & 202,2 & 205,7 & 213,8 \\
\hline Siberian Federal District & 219,5 & 211,3 & 214,9 & 217,7 & 204,4 & 213,6 \\
\hline Russian Federation & 220,2 & 218,4 & 216,9 & 221,8 & 212,8 & 218,0 \\
\hline Irkutsk region & 3223,2 & 3407,1 & 3445,6 & 3257,9 & 3376,1 & 3342,0 \\
\hline Siberian Federal District & 3373,7 & 3676,5 & 3536,1 & 3537,7 & 3641,3 & 3553,1 \\
\hline Russian Federation & 2663,1 & 2989,1 & 2874,9 & 3116,7 & 3172,1 & 2963,2 \\
\hline \multicolumn{7}{|c|}{ Diseases characterized by high blood pressure } \\
\hline Irkutsk region & 735,4 & 942,8 & 1047,7 & 915,2 & 1027,7 & 933,8 \\
\hline Siberian Federal District & 900,9 & 999,5 & 1074 & 1155,1 & 1209,1 & 1067,7 \\
\hline Russian Federation & 587,5 & 617,4 & 690,7 & 898,3 & 954,9 & 749,8 \\
\hline \multicolumn{7}{|c|}{ Diseases of digestive system } \\
\hline Irkutsk region & 4153,7 & 4315,2 & 5466,7 & 5497,7 & 5859,5 & 5058,6 \\
\hline Siberian Federal District & 5613,2 & 5722,8 & 5801,6 & 5664,4 & 5420,6 & 5644,5 \\
\hline Russian Federation & 3478,9 & 3526,6 & 3652,4 & 3526,6 & 3568 & 3550,5 \\
\hline \multicolumn{7}{|c|}{ incl. gastric ulcer and duodenal ulcer } \\
\hline Irkutsk region & 129,0 & 140,8 & 127,2 & 105,8 & 112,5 & 123,1 \\
\hline Siberian Federal District & 131,2 & 127 & 122,6 & 119,4 & 120,2 & 124,1 \\
\hline Russian Federation & 86,9 & 83 & 79,3 & 85,6 & 83,5 & 83,7 \\
\hline
\end{tabular}


As it follows from the data in Table 3, the incidence of blood diseases, for the period 2012-2016, made 577.1, which is 22.8 $\%$ higher than the Russia's average index, and $11.2 \%$ higher than the regional index for Siberian Federal District (SFO). The blood diseases incidence dynamics of the Irkutsk region population is characterized by a pronounced growth trend. The growth rate for 5 years made $14.8 \%$. The index increased from 529.3 in 2012 to 607.4 in 2016.

$91.3 \%$ in the structure of blood diseases morbidity belong to anemia. The incidence of anemia in Irkutsk region in the average for the period 2012-2016 was 526.9, which is $22.6 \%$ higher than Russia's average and $10.0 \%$ higher than the regional index for Siberian Federal District. The anemia incidence dynamics of the population in Irkutsk region is also characterized by a pronounced growth trend. The growth rate for 5 years made $13.8 \%$. This index increased from 481.9 in 2012 to 548.5 in 2016.

The long-term annual average level of endocrine system primary incidence in Irkutsk region for the period 2012-2016 was 1857.4, which is $55.6 \%$ higher than Russia's average, and $17.9 \%$ higher than the regional index. The incidence dynamics of the Irkutsk region population with endocrine system diseases is characterized by a growth trend. The growth rate for 5 years was $13.0 \%$. The incidence rate increased from 1784.7 in 2012 to 2017.0 in 2016.

In the structure of "endocrine system" class, a significant proportion $(36.2 \%)$ belongs to thyroid disease. The incidence rate of the Irkutsk region population with the given pathology over the period 20122016 averaged to 672.7 , which is $91.8 \%$ higher than the national average, and 41.2 $\%$ higher than the regional index. The incidence dynamics of Irkutsk region's popula- tion with thyroid gland diseases is characterized by the emerging tendency of growth. The growth rate for 5 years made $9.9 \%$. This index increased from 664.1 in 2012 to 730.1 in 2016.

Thyrotoxicosis makes $1.2 \%$ in the endocrine system diseases incidence. The long-term annual average level of thyrotoxicosis primary incidence in Irkutsk region for the period 2012-2016 was 22.5, which is $43.6 \%$ higher than Russia's average, and $15 \%$ higher than the regional index. Thyrotoxicosis incidence dynamics of the Irkutsk region population in 2012-2014 was characterized by a downward trend; in 2014-2016 the growth in this index was registered from 19.4 to 25.8 . The growth rate for 3 years was $13.0 \%$.

In the structure of endocrine system diseases incidence, $17.4 \%$ is obesity. The incidence rate of the Irkutsk region population with this pathology averaged 322.3 over the period 2012-2016, which is $30 \%$ higher than the Russia's average, and $18 \%$ lower than the regional index. It should be noted that the morbidity dynamics in the Irkutsk region population is characterized by a pronounced growth trend. The growth rate for the analyzed period was $46.8 \%$. This index increased from 250.4 in 2012 to 367.7 in 2016.

The incidence of type 2 diabetes mellitus is $11.5 \%$ in the endocrine system diseases morbidity structure. The long-term annual average level of type 2 diabetes mellitus primary incidence in the Irkutsk region population for the period 20122016 was 213.8 , which is $1.9 \%$ lower than the Russia's average. The dynamics of type 2 diabetes mellitus morbidity in Irkutsk Region was characterized by a downward trend. The decrease rate for the period under study was $-8.4 \%$.

The long-term annual average level of circulatory system diseases primary inci- 
dence in the population of Irkutsk region, for the period 2012-2016, was 3342.0, which is $12.8 \%$ higher than the Russia's average, and $5.9 \%$ lower than the regional index. The incidence dynamics of circulatory system diseases in the Irkutsk region is characterized by an emerging tendency of growth. The growth rate for the analyzed period was $4.7 \%$. This index increased from 3223.2 in 2012 to 3376.1 in 2016.

In the incidence structure of circulatory system diseases, $27.9 \%$ are the diseases characterized by high blood pressure. The incidence rate of the Irkutsk region population with this pathology averaged 933.8 over the period 2012-2016, which is 24.5 $\%$ higher, than the Russia's average and $12.5 \%$ lower than the regional index. The incidence dynamics of the Irkutsk region population with the diseases characterized by high blood pressure featured a pronounced growth trend. The growth rate for the analyzed period was $39.7 \%$. This index increased from 735.4 in 2012 to 1027.7 in 2016.

The long-term annual average level of primary incidence of digestive organs diseases in the Irkutsk region population for the period 2012-2016 was 5058.6, which is $42.5 \%$ higher than the Russia's average, and $10.4 \%$ lower than the regional index. The incidence dynamics of the Irkutsk region's population with digestive organs diseases was characterized by a pronounced growth trend. The growth rate for the analyzed period was $41.1 \%$. The index increased from 4153.7 in 2012 to 5859.5 in 2016.

In the incidence structure of the digestive system diseases, $18.3 \%$ is gastritis and duodenitis, $2.4 \%$ belong to gastric ulcer and duodenal ulcer. The morbidity rate among the Irkutsk region's population with gastritis and duodenitis over the period
2012-2016 averaged 927.3, which is 88.3 $\%$ higher than the Russia's average index and $30.4 \%$ than the regional index. The incidence dynamics of the Irkutsk region population with gastritis and duodenitis was characterized by a pronounced growth trend. The growth rate for the analyzed period was $31.9 \%$. The index increased from 794.4 in 2012 to 1047.7 in 2016.

The incidence rate of the Irkutsk region's population regarding to stomach ulcer and duodenal ulcer over the period 2012-2016 averaged 123.1, which is 47.1 $\%$ higher than the national average. The morbidity dynamics of this pathology in the Irkutsk region's population was characterized by a downward trend. The decrease rate in this index for the analyzed period made $-12.8 \%$. The incidence rate declined from 129.0 in 2012 to 112.5 in 2016.

Thus, our findings testify the deficit in consumption of the main groups of food products formed in the residents of Irkutsk region due to unbalanced nutrition. In the region, health disorders manifested in the development of alimentary-dependent types of pathology are registered. The indices of such incidence, comparing to the Russia's average, are higher. Unhealthy diet is a risk factor for a number of diseases. In particular, the blood diseases, endocrine system diseases (obesity, thyroid disease, thyrotoxicosis) can be noted, as well as the diseases characterized by high blood pressure, digestive system disorders.

All of the above indicates the need for taking measures to improve the nutrition quality of the population. One of the important components is the implementation of measures aimed at improving the food products mix in retail, catering enterprises, as well as increasing the economic accessibility and attraction of healthy foods $[4,5]$. 
The study findings were used to conduct a comprehensive assessment of the risk factors effect on public health. Information and proposals on the problem of improper diet in Irkutsk region, and the need to adopt prevention programs for alimentary-dependent diseases were submitted to the Governor of Irkutsk region, local authorities, other interested bodies and organizations with a view to make relevant management decisions.

Funding. Our research was not granted any sponsors' support.

A conflict of interests. The authors state there is no conflict of interests.

\section{References}

1. Onishchenko G.G. Kontseptsiya gosudarstvennoi politiki v oblasti zdorovogo pitaniya: sotsal'no-gigienicheskii monitoring [State policy concept in the sphere of healthy nutrition: social and hygienic monitoring]. Zdorovoe pitanie: vospitanie, obrazovanie, reklama: materialy Vserossiiskoi nauchno-prakticheskoi konferentsii. Moscow, 2001, pp. 147 (in Russian).

2. Tutel'yan V.A. Gigiena pitaniya: sovremennye problemy [Food hygiene: current problems]. Zdravookhranenie RF, 2008, no. 1, pp. 8-9 (in Russian).

3. Tutel'yan V.A. O normakh fiziologicheskikh potrebnostei v energii i pishchevykh veshchestvakh dlya razlichnykh grupp naseleniya Rossiiskoi Federatsii [Norms of physiological requirements in energy and nutrients in various groups of population in Russian Federation]. $\mathrm{Vo}$ prosy pitaniya, 2009, vol. 78, no. 1, pp. 4-16 (in Russian).

4. VOZ. Informatsionnyi byulleten'. Zdorovoe pitanie. Oktyabr' 2017 [The WHO. Information bulletin. Healthy nutrition. October 2017]. Sotsial'nye aspekty zdorov'ya naseleniya: elektronnyi nauchnyi zhurnal, 2017. Available at: http: //vestnik.mednet.ru/content/view/941/30/lang,ru/ (30.01.2018) (in Russian).

5. Evropeiskii plan deistvii v oblasti pishchevykh produktov i pitaniya na 2015-2020 gg. [European plan of actions in the sphere of food products and nutrition for 2015-2020]. Vsemirnaya organizatsiya zdravookhraneniya: ofitsial'nyi sait. Available at: http://www.euro.who.int/ru/health-topics/disease-prevention/nutrition/publications/2015/european-food-and-nutrition-action-plan-20152020-2014 (13.03.2018) (in Russian).

6. Candari C.J., Cylus J., Nolte E. Assessing the economic costs of unhealthy diets and low physical activity: an evidence review and proposed framework. World Health Organization, 2017, 91 p. Available at: http: //www.euro.who.int/en/publications/abstracts/assessing-theeconomic-costs-of-unhealthy-diets-and-low-physical-activity-an-evidence-review-andproposed-framework-2017 (30.01.2018).

7. Rees K., Hartley L., Flowers N., Clarke A., Hooper L., Thorogood M., Stranges S. 'Mediterranean' dietary pattern for the primary prevention of cardiovascular disease. Cochrane Database Syst Rev., 2013, vol. 12, no. 8, pp. CD009825. DOI: 10.1002/14651858.CD009825.pub2.

8. Strobl R., Müller M., Emeny R., Peters A., Grill E. Distribution and determinants of functioning and disability in aged adults - results from the German KORA-Age study. BMC Public Health, 2013, vol. 13, pp. 137. DOI: 10.1186/1471-2458-13-137.

9. Summerbell C.D., Moore H.J., Vögele C., Kreichauf S., Wildgruber A., Manios Y., Douthwaite W., Nixon C.A., Gibson E.L. Evidence-based recommendations for the development of obesity prevention programs targeted at preschool children. Obesity Reviews, 2012, vol. 13, no. s1, pp. 129-132. DOI: 10.1111/j.1467-789X.2011.00940.x

10. Te Morenga L., Mallard S., Mann J. Dietary sugars and body weight: systematic review and meta-analyses of randomised controlled trials and cohort studies. BMJ, 2013, vol. 346, pp. e7492. DOI: 10.1136/bmj.e7492 
11. Thow A.M., Jan S., Leeder S., Swinburn B. The effect of fiscal policy on diet, obesity and chronic disease: a systematic review. Bull World Health Organ, 2010, vol. 88, no. 8, pp. 609-614.

12. WHO estimates of the global burden of foodborne diseases: Foodborne disease burden epidemiology reference group 2007-2015. World Health Organization, 2015, 255 p. Available at: http: //apps.who.int/iris/handle/10665/199350 (30.01.2018).

13. Efimova N.V., Katul'skaya O.Yu., Zhdanova I.G. Alimentarno-zavisimaya patologiya u detskogo i podrostkovogo naseleniya Irkutskoi oblasti [Alimentary depended pathology at children and teenagers in Irkutsk oblast]. Izvestiya Samarskogo nauchnogo tsentra RAN, 2012, vol. 14 , no. 5 (2), pp. 333-335 (in Russian).

14. Potreblenie produktov pitaniya $\mathrm{v}$ domashnikh khozyaistvakh [Food products consumption by households]. Federal'naya sluzhba gosudarstvennoi statistiki: ofitsial'nyi sait. Available at: http: $\quad$ /www.gks.ru/wps/wcm/connect/rosstat_main/rosstat/ru/statistics/publications/catalog/doc_1140095125312 (30.01.2018) (in Russian).

15. Regiony Rossii. Sotsial'no-ekonomicheskie pokazateli [Russian regions. Social and economic indexes]. Federal'naya sluzhba gosudarstvennoi statistiki: ofitsial'nyi sait. Available at: http: //www.gks.ru/wps/wcm/connect/rosstat_main/rosstat/ru/statistics/publications/catalog/doc_1138623506156 (30.01.2018) (in Russian).

16. Zabolevaemost' vsego naseleniya Rossii v 2013 godu: Statisticheskie materialy za 2012-2013 gg. [Population morbidity in Russia in 2013: Statistic data over 2012-2013]. Ministerstvo zdravookhraneniya Rossiiskoi Federatsii: ofitsial'nyi sait. Available at: https://wwwtest.rosminzdrav.ru/special/ministry/61/22/stranitsa-979/statisticheskaya-informatsiyaminzdrava-rossii (30.01.2018) (in Russian).

17. Zabolevaemost' vsego naseleniya Rossii v 2015 godu: Statisticheskie materialy za 2014-2015 gg. [Population morbidity in Russia in 2015: Statistic data over 2014-2015]. Ministerstvo zdravookhraneniya Rossiiskoi Federatsii: ofitsial'nyi sait. Available at: https: //wwwtest.rosminzdrav.ru/special/ministry/61/22/stranitsa-979/statisticheskaya-informatsiyaminzdrava-rossii (30.01.2018) (in Russian).

18. Zabolevaemost' vsego naseleniya Rossii v 2016 godu: Statisticheskii sbornik 2016 god [Population morbidity in Russia in 2016: Statistic data over 2016]. Ministerstvo zdravookhraneniya Rossiiskoi Federatsii: ofitsial'nyi sait. Available at: https: //www.rosminzdrav.ru/ministry/61/22/stranitsa-979/statisticheskie-i-informatsionnyematerialy/statisticheskiy-sbornik-2016-god (30.01.2018) (in Russian).

Zhdanova-Zaplesvichko I.G. Irrational nutrition as populattion health risk factor in Irkutsk region. Health Risk Analysis, 2018, no. 2, pp. 23-32. DOI: 10.21668/health.risk/2018.2.03.eng

Received: 09.04.2018

Accepted: 17.06.2018

Published: 30.06.2018 